\title{
THERMO-HYDROMETRIC ARGUMENTS IN THE DEMONSTRATION OF FOEHNAL CIRCULATION IN COTNARI, ROMANIA
}

DOI: http://dx.doi.org/10.18509/GBP.2020.25

UDC: 551.555.3:551.506]:551.584.5(498)

\author{
Lidia Maria Apopei ${ }^{1}$ \\ Dumitru Mihăilă ${ }^{1}$ \\ Petruț Ionel-Bistricean ${ }^{2}$ \\ ${ }^{1}$ Department of Geography, Faculty of History and Geography, Stefan cel Mare University, \\ Suceava, Romania \\ ${ }^{2}$ Regional Meteorological Centre of Moldova, National Meteorological Administration, \\ Suceava, Romania
}

\begin{abstract}
The foehnal circulation from Cotnari is a meteorological reality demonstrated through the statistical, cartographic and graphical analyses realized on the basis of the data processing of a program of hourly observations made in 12 representative points of the researched territory, carried out for 8 months. Our analyses confirm that from a thermal point of view the foehn brings an average thermal increase of $1.3-1.5^{\circ} \mathrm{C}$ and a hygric deficit of 8-9\%. In clear cases with foehn (that represent $4.5 \%$ of the time monitored), the thermal and hygric consequences are doubled in value.
\end{abstract}

Keywords: thermo-hygrometric sensors, urban atmosphere, topoclimates

\section{INTRODUCTION}

The foehn should be defined by its characteristics and not according to its origin [1]. Although the foehn is defined as "the wind warmed and dried by the downward movement, generally on the sheltered slope of a mountain" [2], [The World Meteorological Organization, 1992], the identification of the periods with foehn for each geographical region, creates real problems for researchers. Currently, there are no generally accepted specific value thresholds for meteorological elements (air temperature, relative humidity of the air, air pressure, the speed or wind direction) based on which we can classify dynamic manifestations in a particular area or region in the foehn interval category [3].

The choice of foehn / non foehn limits is influenced by the regional synoptic conditions, the particularities of the local dynamics and topography [4]. The previous climatological observations and analyses are important because they have indicated, in different ways, the existence of foehnal manifestations in a certain area. The analysis and interpretation of the foehn is at the discretion of the researcher considering the key characteristics of this type of wind [2]:

- the dynamics of the air and the perpendicular orientation of the wind lines when encountering an orographic obstacle,

- the increase of the air temperature and the reduction of the relative humidity on the slope opposite to the air circulation.

The recent European studies outline through the variety of approaches (aerological surveys, mathematical models, IT programs, graphical simulations), the ubiquity of the foehn where the wind lines are forced to cross a orographic obstacle. Starting from the 
MAP project (The Mesoscale Alpine Program, 1999), meteorologists from the MeteoSWISS service established in 2008 the quantitative limits specific to the foehn witin Central Europe (applying them to the geographical area adjacent to the Alps).

They have considered parameters such as wind direction / speed and pressure gradient that was $4 \mathrm{hPa}$ for the mountain floor ( $8 \mathrm{hPa}$ for the adjacent terrain). These parameters come from the MOS (Model Output Statistics) meteorological database included in the ECMWF (European Center for Medium Range Weather Forecasts) model and were the basis for the development of the computer program for detecting the regional foehn. In Romania, the foehn was analyzed from both points of view of the thermodynamic theory [5], [6], [7], [8] and hydraulic theory [9]. The regions in the country where the foehn has a higher frequency are the sub-mountain areas protected by /from the Carpathian Mountains shelter. To these regions are added the hilly peaks that oppose the dominant circulation. From this last category we stopped at the top of the Hârlău-Tudora Hill, where the manifestation of the foehn is demonstrated by the previous climatic observations [7], [8], [9] and the use of the land for viticulture purposes.

\section{MATERIALS AND METHODS}

\section{Study area}

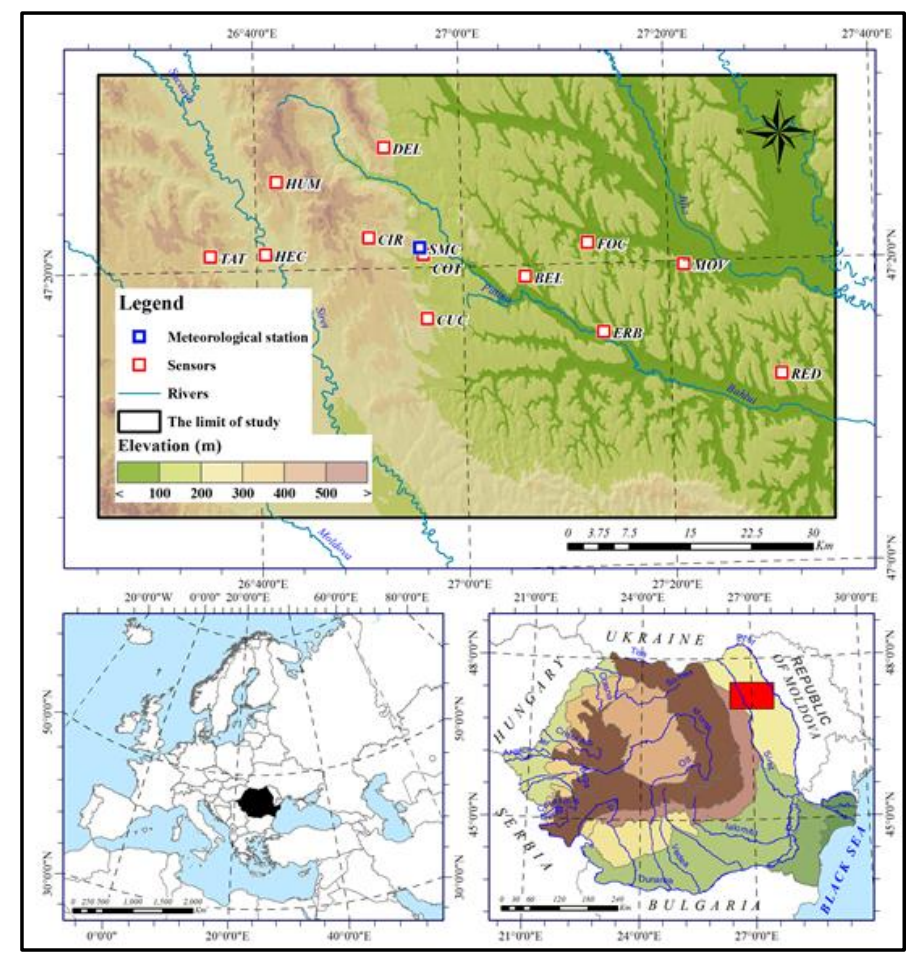

Figure 1. Geographical position of Cotnari area

The Cotnarilor area is located in the northeast of Romania, between Siret Valley and Prut Valley, in the northern half of Iasi County. The study area is developed on an altitude difference of 328 meters (between $391 \mathrm{~m}$ in Humosu Hill and $63 \mathrm{~m}$ in Erbiceni locality located on the Bahlui river valley), longitudinally about $1^{\circ}$ (between $26^{\circ} 35$ 'longitude E to Tătăruşi in the west and $27^{\circ} 30^{\prime}$ 'longitude E to Rediu in the east) and $10^{\prime}$ latitudinal (between the locality Deleni located in the northern extremity at $47^{\circ} 27$ 'lat. $\mathrm{N}$ and the locality Rediu from the southern extremity located at $47^{\circ} 12^{\prime}$ lat.N (Fig. 1). 


\section{METHODS}

To carry out this study we used the meteorological data recorded at the Cotnari Weather Station and the measurements of temperature $\left({ }^{\circ} \mathrm{C}\right)$ and relative humidity $(\%)$ of the air, at 12 weather stations. The recordings from the meteorological stations set up in their own network were made with CEM DT 171 Data Logger sensors, placed in meteorological shelters according to the regulations of the National Meteorological Administration. The choice of places for monitoring the temperature and humidity of the air was made on the north-south oriented posts alignments and longitudinally placed from West to East, in representative physical-geographic conditions (river valley, slope opposite to the advection, sheltered slope, the territory from the east of the sheltered slope on which the foehnal influence is reflected) in order to capture the regional thermohygrical consequences of air dynamics. The weather stations arranged in the order and the specified logic are found in Tab. 1 and Fig. 1. These are: Tătăruşi - the western slope of the Siret river, Heci in the river bed of Siret river, Humosu on the opposite slope of the air advection, Deleni, Cireşeni, Cucuteni, Cotnari on the hilly alignment Dealu MareHârlău and Belceşti weather stations, Focuri, Erbiceni, Movileni in the Jijia-Bahlui hilly plain.

Table 1. Location of observation posts of Cotnari area

\begin{tabular}{cccccc}
\hline $\begin{array}{c}\text { The name of } \\
\text { the weather } \\
\text { station }\end{array}$ & $\begin{array}{c}\text { The code } \\
\text { of the } \\
\text { weather } \\
\text { station }\end{array}$ & Geographical position & $\begin{array}{c}\text { Latitude } \\
\left({ }^{\circ} \text { lat.N.) }\right.\end{array}$ & $\begin{array}{c}\text { Longitude } \\
\left({ }^{\circ} \text { long.E. }\right)\end{array}$ & $\begin{array}{c}\text { Altitude } \\
\text { (m) }\end{array}$ \\
\hline Tătăruși & TAT & $\begin{array}{c}\text { The western slope of } \\
\text { Siret river (WSS) }\end{array}$ & $47^{\circ} 21^{\prime}$ & $26^{\circ} 35^{\prime}$ & 323 \\
\hline Heci & HEC & $\begin{array}{c}\text { The minor riverbed of } \\
\text { Siret }\end{array}$ & $47^{\circ} 21^{\prime}$ & $26^{\circ} 40^{\prime}$ & 217 \\
\hline Humosu & HUM & WSS & $47^{\circ} 25^{\prime}$ & $26^{\circ} 41^{\prime}$ & 391 \\
\hline Cireşeni & CIR & $\begin{array}{c}\text { The hilly alignement of } \\
\text { the peaaks at the west of } \\
\text { Cotnari (HAWC) }\end{array}$ & $47^{\circ} 22^{\prime}$ & $26^{\circ} 50^{\prime}$ & 269 \\
\hline Deleni & DEL & HAWC & $47^{\circ} 27^{\prime}$ & $26^{\circ} 52^{\prime}$ & 312 \\
\hline $\begin{array}{c}\text { Staţia } \\
\text { meteorologică } \\
\text { Cotnari }\end{array}$ & SMC & HAWC & $47^{\circ} 16^{\prime}$ & $26^{\circ} 56^{\prime}$ & 233 \\
\hline Cotnari & COT & Cotnari Cuesta & $47^{\circ} 22^{\prime}$ & $26^{\circ} 56^{\prime}$ & 289 \\
\hline Belceşti & BEL & $\begin{array}{c}\text { The lower plain of Jijia } \\
\text { and Bahlui(LPJB) }\end{array}$ & $47^{\circ} 19^{\prime}$ & $27^{\circ} 05^{\prime}$ & 148 \\
\hline Focuri & FOC & LPJB & $47^{\circ} 22^{\prime}$ & $27^{\circ} 12^{\prime}$ & 104 \\
\hline Erbiceni & ERB & LPJB & $47^{\circ} 15^{\prime}$ & $27^{\circ} 13^{\prime}$ & 63 \\
\hline Movileni & MOV & LPJB & $47^{\circ} 20^{\prime}$ & $27^{\circ} 21^{\prime}$ & 74 \\
\hline Rediu & REB & LPJB & $47^{\circ} 12^{\prime}$ & $27^{\circ} 30^{\prime}$ & 97 \\
\hline
\end{tabular}

We have monitored for the period 01.03.2019 - 31.10.2019 (245 days / 5880 hours) the inter-hourly, inter-diurnal and inter-monthly evolution of the air temperature and relative humidity in the study area. The analysis of the daily synoptic maps from the websites www.watterbote.de, www.pogodynka.pl and www.meteoromania.ro, the aerial surveys available on the website www.weather.uwyo., led, initially, to the identification of the peculiarities of the foehn in area of study.

Graphic materials were created using ArcGIS, Excel 2007 and ClimateOpenAir. 


\section{RESULTS AND DISCUSSIONS}

The study is based on a certain algorithm. i) First of all, we selected the cases in which the wind has beaten from the general western sector (SSW, SW, WSW, W, WNW, NW, NNW). ii) Then, from the resulting database, we extracted the consecutive hourly cases (between 5 and 20 hours) with the wind speed of over $2 \mathrm{~m} / \mathrm{s}$, considering (in agreement with Beaufort's observations, 1805) that above this speed threshold of the wind, the movement of the air can produce obvious foehn effects. iii) For these cases we followed the fulfillment of other additional conditions: the increase of the air temperature and the decrease of the relative humidity at the weather stations located to the east of Cotnari. Later, we analyzed the synoptic maps and the aerological surveys.

Table 2. Periods with foehn in Cotnari area (01.03.2019 - 31.10.2019)

\begin{tabular}{|c|c|c|c|c|c|c|c|c|c|}
\hline \multirow[b]{2}{*}{ Date } & \multirow{2}{*}{$\begin{array}{c}\text { Time } \\
\text { interval }\end{array}$} & \multirow{2}{*}{$\begin{array}{l}\text { No. } \\
\text { hours }\end{array}$} & \multirow{2}{*}{$\begin{array}{c}\text { Average } \\
\text { speed } \\
\text { periods } \\
\text { with } \\
\text { foehn } \\
(\mathrm{m} / \mathrm{s})\end{array}$} & \multicolumn{3}{|c|}{$\begin{array}{l}\text { Maximum wind speed } \\
\qquad(\mathrm{m} / \mathrm{s})\end{array}$} & \multirow{2}{*}{$\begin{array}{c}\text { The } \\
\text { average } \\
\text { value of } \\
\text { air } \\
\text { pressure } \\
\text { periods } \\
\text { with foehn } \\
\text { (mb) }\end{array}$} & \multirow{2}{*}{$\begin{array}{c}\text { The } \\
\text { average } \\
\text { value of } \\
\text { air } \\
\text { temperatur } \\
\text { e } \\
\text { periods } \\
\text { with foehn } \\
\left({ }^{\circ} \mathrm{C}\right) \\
\end{array}$} & \multirow{2}{*}{$\begin{array}{c}\text { The } \\
\text { average } \\
\text { value of } \\
\text { relative } \\
\text { humidity } \\
\text { periods } \\
\text { with foehn } \\
(\%)\end{array}$} \\
\hline & & & & speed & hour & direction & & & \\
\hline 01.03.2019 & $\begin{array}{l}02: 30- \\
20: 30 \\
\end{array}$ & 18 & 8.5 & 12.0 & $\begin{array}{l}07: 30 \\
08: 00 \\
\end{array}$ & $\begin{array}{c}\text { NNV } \\
\text { NV }\end{array}$ & 1004.1 & 7.0 & 50.1 \\
\hline 10.03.2019 & $\begin{array}{c}08: 30- \\
19: 30 \\
\end{array}$ & 11 & 8.4 & 14.0 & $13: 30$ & V & 1009.4 & 11.3 & 43.0 \\
\hline 11.03.2019 & $\begin{array}{c}07: 30- \\
17: 30 \\
\end{array}$ & 10 & 8.0 & 13.0 & $12: 30$ & NV & 1005.2 & 12.2 & 37.5 \\
\hline 23.03.2019 & $\begin{array}{l}05: 30- \\
20: 30\end{array}$ & 15 & 7.9 & 10.0 & $\begin{array}{l}10: 30 \\
14: 30 \\
15: 30 \\
\end{array}$ & $\begin{array}{l}\text { NV } \\
\text { NNV }\end{array}$ & 1026.1 & 9.0 & 32.0 \\
\hline 26.03.2019 & $\begin{array}{c}04: 30- \\
19: 30 \\
\end{array}$ & 13 & 5.0 & 6.0 & $\begin{array}{l}08: 30 \\
13: 30 \\
\end{array}$ & NV & 1017.0 & 5.4 & 71.9 \\
\hline 30.03.2019 & $\begin{array}{c}05: 30- \\
14: 30 \\
\end{array}$ & 9 & 6.5 & 7.0 & $\begin{array}{l}05: 30 \\
04: 30 \\
\end{array}$ & NV & 1025.8 & 12.6 & 55.8 \\
\hline 10.04 .2019 & $\begin{array}{c}02: 30- \\
16: 30\end{array}$ & 14 & 5.2 & 7.0 & $07: 30$ & $\mathrm{NV}$ & 1007.4 & 15.9 & 65.6 \\
\hline 20.04.2019 & $\begin{array}{c}00: 00- \\
14: 30 \\
\end{array}$ & 14 & 3.5 & 4.0 & $\begin{array}{l}03: 30 \\
11: 30 \\
\end{array}$ & NV & 1029.2 & 8.5 & 73.1 \\
\hline 28.04. 2019 & $\begin{array}{c}04: 30- \\
09: 30\end{array}$ & 5 & 3.5 & 5.0 & $06: 30$ & $\mathrm{~V}$ & 1007.9 & 15.6 & 67.5 \\
\hline 08.05.2019 & $\begin{array}{l}02: 30- \\
16: 30\end{array}$ & 14 & 10.4 & 14.0 & $\begin{array}{l}04: 30 \\
06: 30\end{array}$ & NV & 1013.9 & 9.3 & 75.7 \\
\hline $\begin{array}{c}25,26.05 . \\
2019 \\
\end{array}$ & $\begin{array}{c}21: 30- \\
14: 30 \\
\end{array}$ & 17 & 5.8 & 8.0 & $\begin{array}{l}05: 30 \\
07.30 \\
\end{array}$ & V & 1014.1 & 12.6 & 55.8 \\
\hline 18.06.2019 & $\begin{array}{c}00: 30- \\
13: 30 \\
\end{array}$ & 13 & 4.5 & 5.0 & $\begin{array}{l}07.30 \\
10.30 \\
\end{array}$ & NV & 1017.9 & 22.9 & 74.7 \\
\hline 28.06.2019 & $\begin{array}{l}05: 30- \\
20: 30 \\
\end{array}$ & 15 & 8.7 & 10.0 & $\begin{array}{l}05: 30 \\
17: 30 \\
\end{array}$ & NV & 1013.9 & 21.3 & 52.9 \\
\hline 22.07.2019 & $\begin{array}{c}00: 30- \\
13: 30 \\
\end{array}$ & 13 & 4.3 & 8.0 & 03:30 & NV & 1019.4 & 23.3 & 69.0 \\
\hline 31.07.2019 & $\begin{array}{c}02: 30- \\
14: 30\end{array}$ & 12 & 5.8 & 8.0 & 09:30 & NNV & 1008.1 & 24.9 & 67.2 \\
\hline 22.08.2019 & $\begin{array}{l}00: 30- \\
20: 30\end{array}$ & 20 & 8.0 & 10 & $\begin{array}{l}02: 30 \\
05.30\end{array}$ & NV & 1023.6 & 21.9 & 69.4 \\
\hline 03.09.2019 & $\begin{array}{c}05: 30- \\
16: 30 \\
\end{array}$ & 11 & 5.0 & 7.0 & $\begin{array}{l}11: 30 \\
12: 30 \\
\end{array}$ & NV & 1015.5 & 24.8 & 61.8 \\
\hline 16.09.2019 & $\begin{array}{c}02: 30- \\
10: 30 \\
\end{array}$ & 8 & 4.7 & 7.0 & $\begin{array}{l}03: 30 \\
05.30 \\
\end{array}$ & V & 1018.0 & 14.8 & 60.8 \\
\hline 22.09.2019 & $\begin{array}{c}02: 30- \\
13: 30 \\
\end{array}$ & 11 & 4.5 & 7.0 & $\begin{array}{l}04: 30 \\
05.30 \\
\end{array}$ & $\mathrm{~V}$ & 1022.5 & 14.2 & 58.2 \\
\hline 11.10.2019 & $\begin{array}{c}00: 00- \\
14: 30\end{array}$ & 14 & 5.2 & 7.0 & $\begin{array}{l}06: 30 \\
08: 30 \\
\end{array}$ & V & 1021.0 & 13.8 & 66.5 \\
\hline \multicolumn{2}{|c|}{ 01.03.2019-31.10.2019 } & 266 & 6.2 & & & & $1016.0 \mathrm{mb}$ & $15.0^{\circ} \mathrm{C}$ & $60.5 \%$ \\
\hline
\end{tabular}


Based on our own observations, for the period 01.03.2019-31.10.2019, were identified, in the current stage of the research, twenty periods with foehn (Table 2) during which we noticed more particularities of the weather parameters.

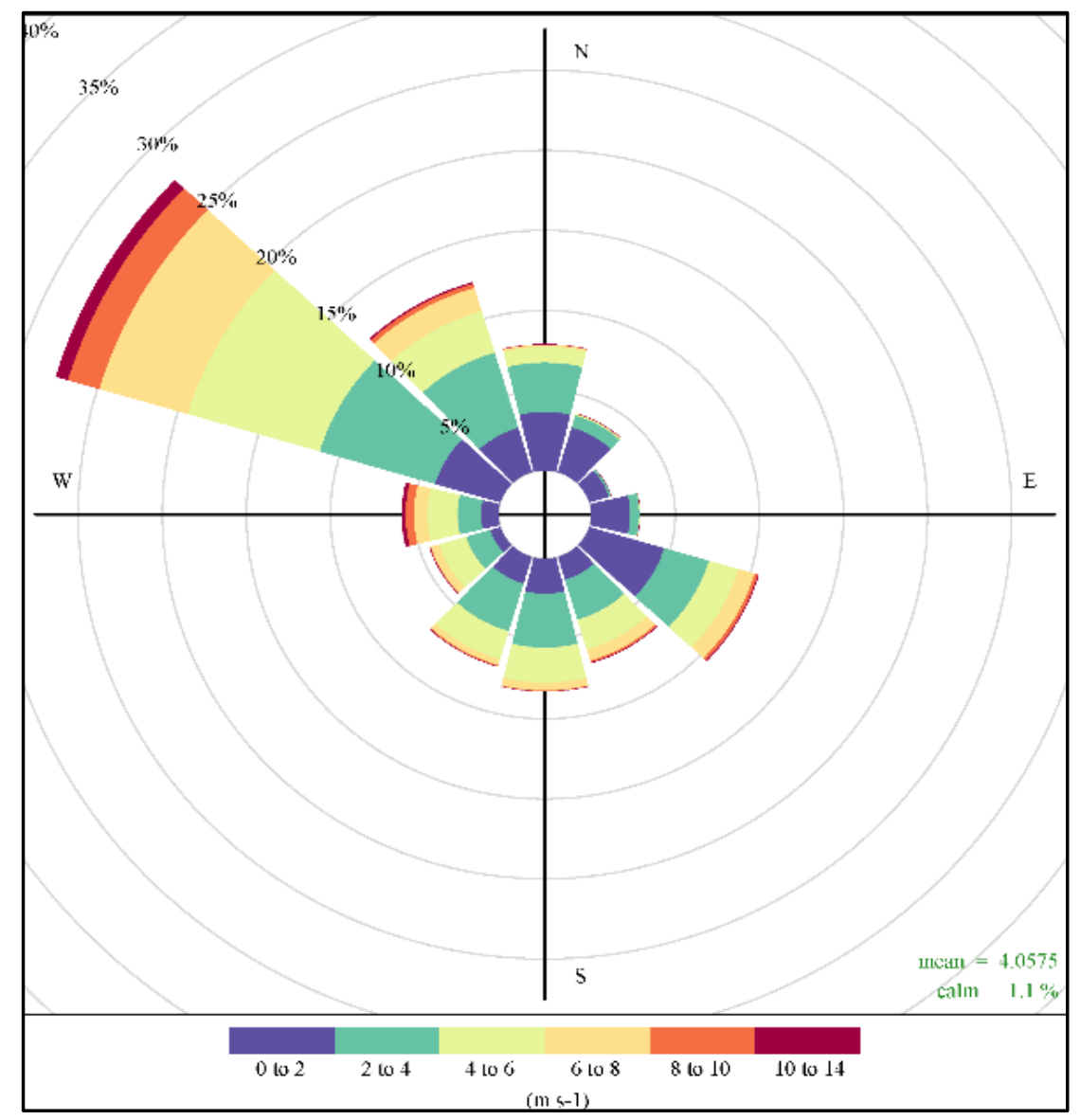

Figure 2. Annual frequency of counts by wind direction (\%)

1.The western circulation was dominant, during the analyzed period 01.03. 2019 - 31. 10. 2019, in the air dynamics with an average percentage of 58\% (Fig. 2, Fig. 3). This circulation, in accordance with the NNW-SSE arrangement of the major lines of the relief, favors air foehnization in the eastern sector of the study area. The synoptic maps of Europe indicated in periods with foehn, advancements of western air masses to the east and south-east of the continent. In what concerns Romania, the western air climbs the Oriental Carpathians and flows towards the Siret Pass. In this low altitude space, the air can sediment on anticyclonic time with clear weather and atmospheric calm favors the thermal inversions or it can climb the western hills toward the Moldavian Plain. The low altitudes of the orographic barrier, of only 400 - 500 m (Dealul Mare Hârlău-Tudora 587 m) and the presence of the low subunits: Şaua Vorona (N) and Şaua Ruginoasa (S), do not favor a major overheating as it happens in the Sub-Carpathians of Curve. , Făgăraş Depression, northwest of Oltenia or Alba Iulia-Turda Corridor. 


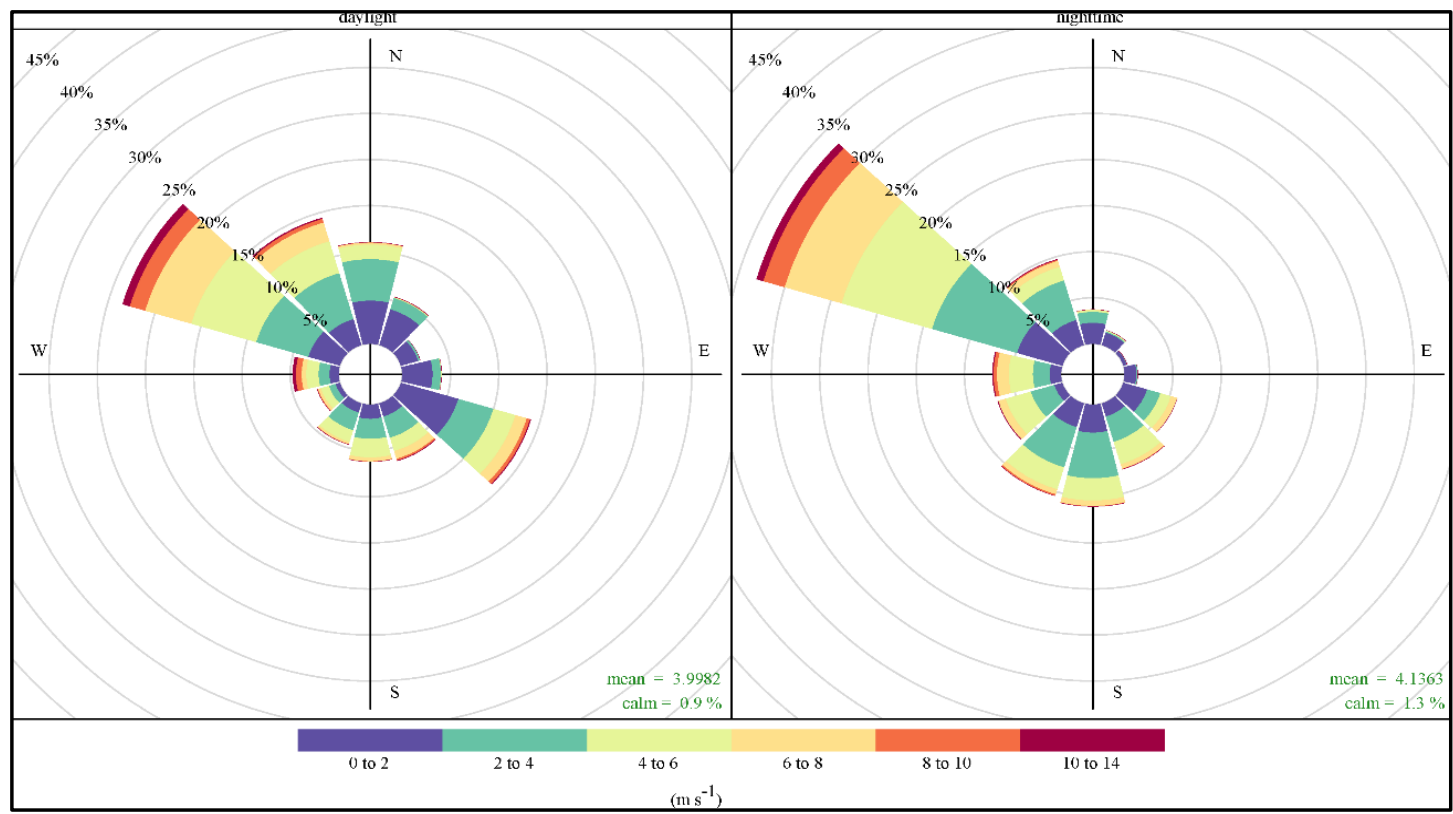

Figure 3. Day/night frequency of counts by wind direction (\%)

2. The incidence of foehn periods did not exclude, according to the dominant dynamics, any of the eight analyzed (Fig. 4). The maximum number of cases with foehn was recorded during spring and the minimum during summer. March was characterized by identifying six periods with foehn and the most representative hourly interval with gusts and wind speeds over $10 \mathrm{~m} / \mathrm{s}$ (42 hours). In August, a foehn episode was identified, characterized by the rapid increase of air pressure at the Cotnari weather station, from 1020 to $1025 \mathrm{mb} /$ between 00:30 and 11:30 and thermal differences over $10.0^{\circ} \mathrm{C} /$ between 05:30 and 10:30 at the observed weather station located to the east of Cotnari, respectively: Belceşti, Erbiceni, Focuri, Movileni, Rediu.

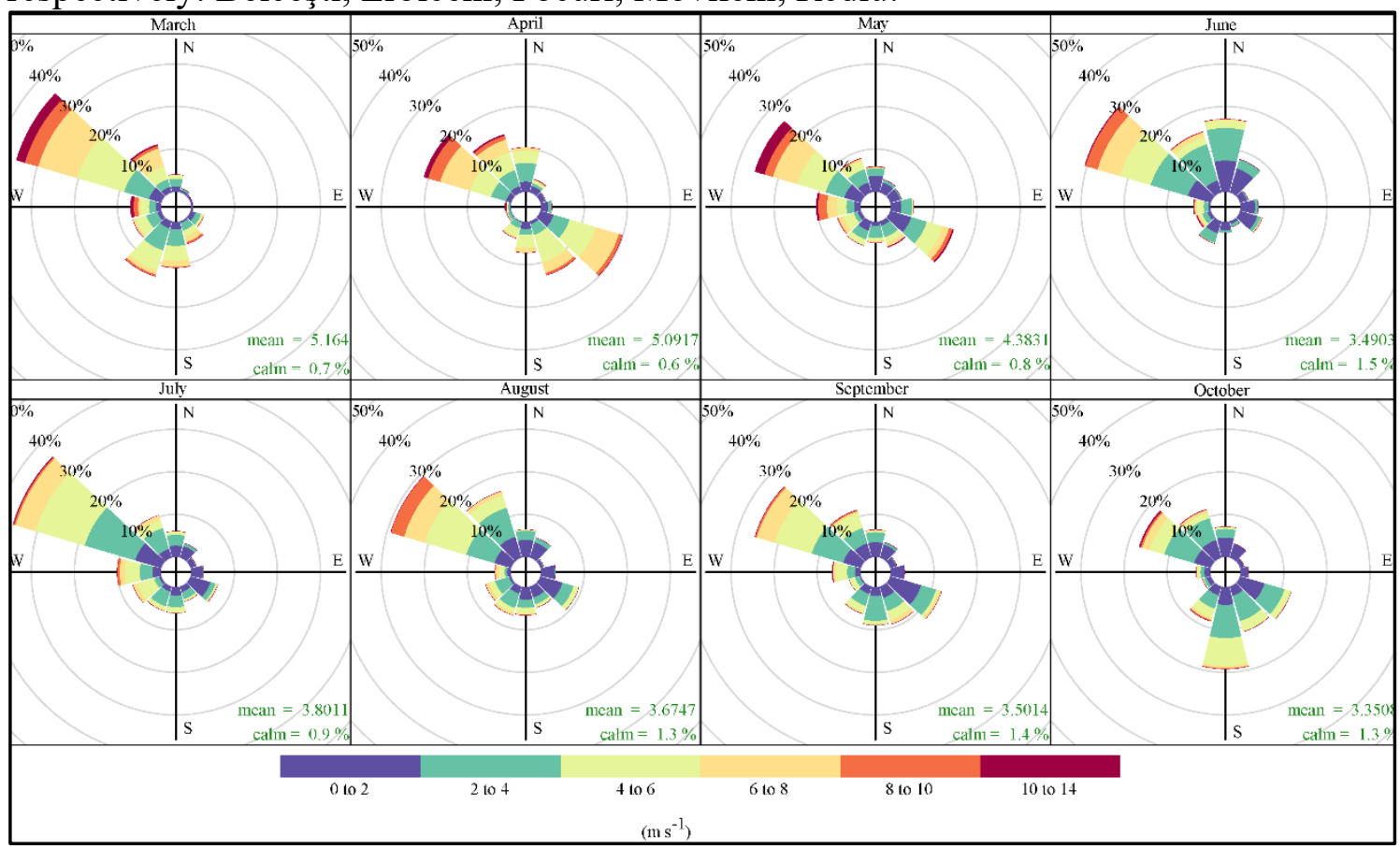

Figure 4. Monthly frequency of counts by wind direction (\%) 
In selecting the beginning of the hourly intervals with foehn, the increase of the wind speed was taken into account, the foehnal intervals ending with a reduction of the speed at the initial values. The high frequency of the foehn was highlighted between 03:30 and 12:30, during which gusts of wind speeds of over $10 \mathrm{~m} / \mathrm{s}$ were recorded, characteristic especially of the sunrise hours between 05: 30-08: 30 (Fig. 5a, Fig. 5b).

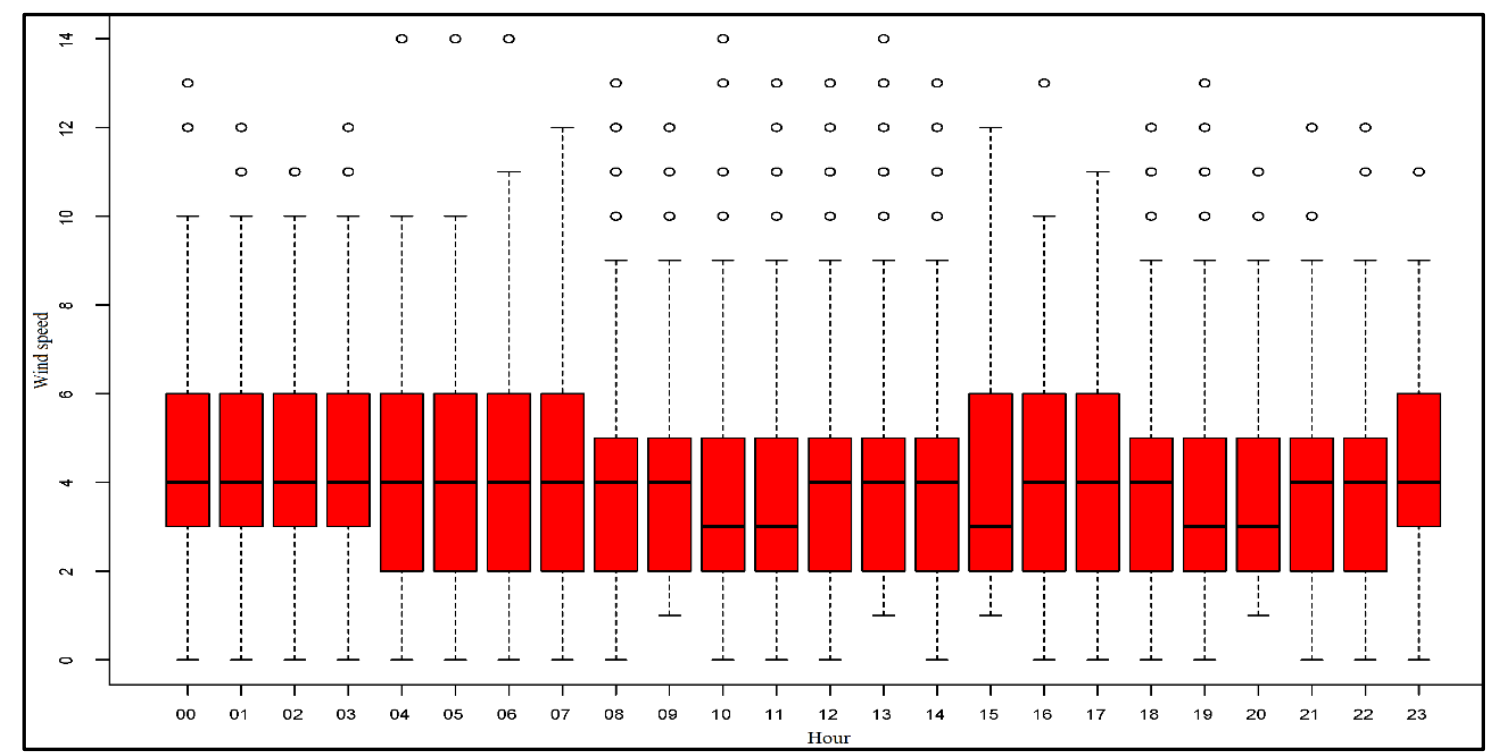

Figure 5a. Average hourly frequency of wind speed at Cotnari Weather Station (01.03.2019-31.10.2019)

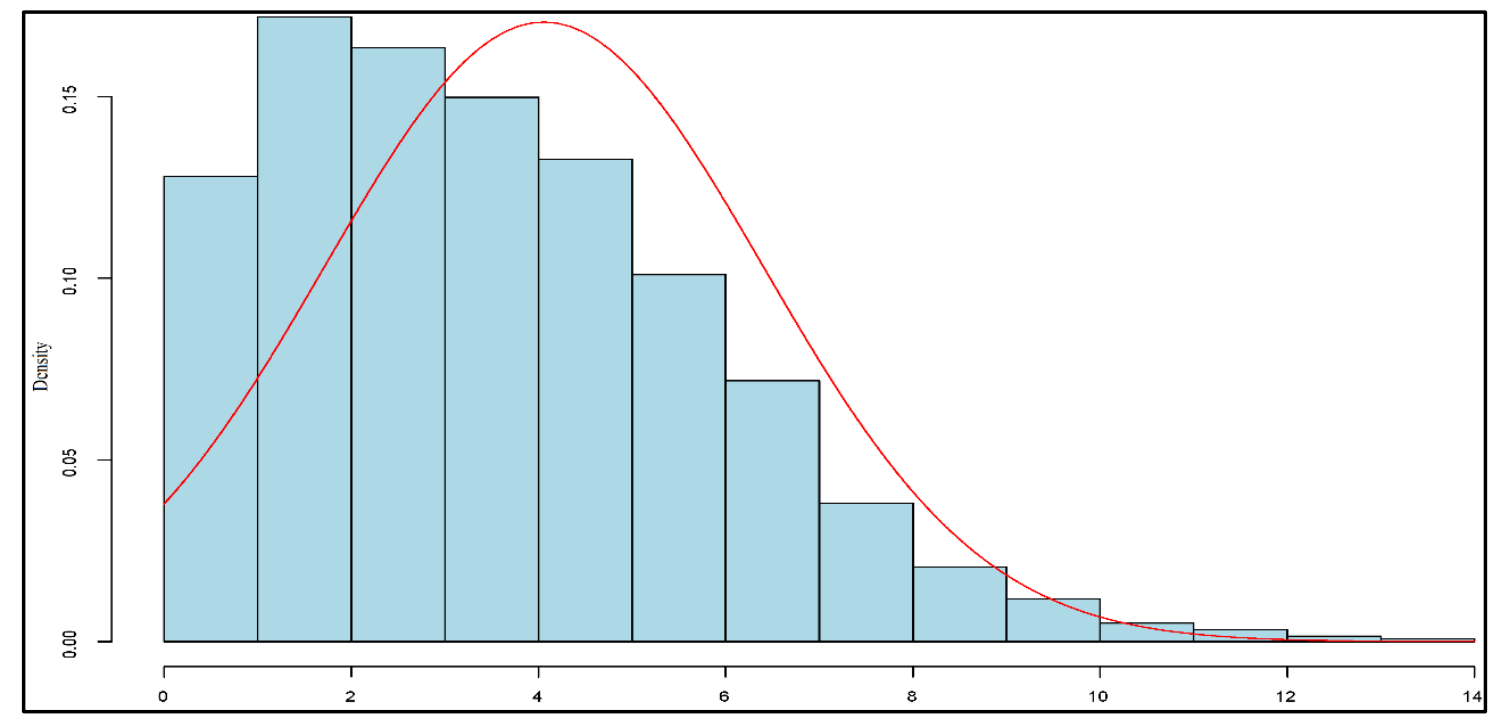

Figure $5 \mathrm{~b}$. The real distribution of wind speed $(\mathrm{m} / \mathrm{s})$ from the theoretical distribution at Cotnari Weather Station (01.03.2019-31.10.2019)

3. After monitoring for 8 months (between 01.03.2019 at 00:30:00 and 31.10.2019 at 23:30:00) the temperature and relative humidity of the air for the 12 weather stations located to the west and east of Cotnari and processing the data from the field, we were able to capture several aspects. 

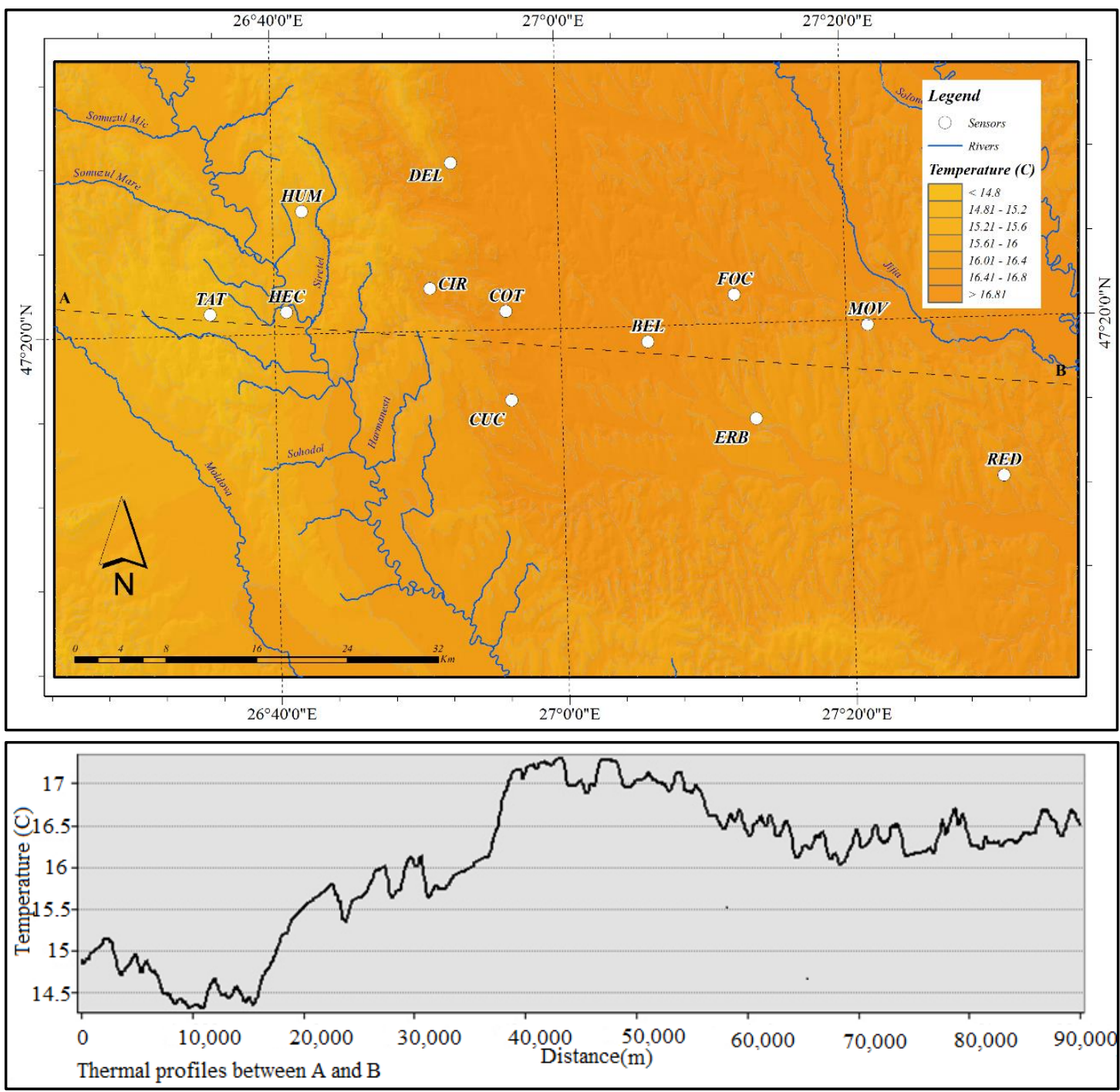

Figure 6. The thermal field at the height of $2 \mathrm{~m}$ from Cotnari surroundings - the average situation between 01.03.2019 at 00:30:00 and 31.10.2019 at 23:30:00 - above; thermal profile between the western and eastern extremities of the investigated territory - below

In terms of thermal changes, we noticed the very strong increase of the air temperature from average values around $14.5-15^{\circ} \mathrm{C}$ to the west and near the main hilly peak on which Humosu weather station is located, up to $17-17.5^{\circ} \mathrm{C}$ between Cotnari and Belcești, to the east of the main hilly alignment responsible for the genesis of the foehnal circulation (Fig. 6). Taking into account the average altitude gap of $232 \mathrm{~m}$ between Humosu and Cotnari-Belcești weather stations, the average thermal difference of $2.5^{\circ} \mathrm{C}$ between them and the average thermal gradient value of $0.46^{\circ} \mathrm{C} / 100 \mathrm{~m}$ specific to the Moldavian Plain [10 ], we can assign the additional thermal difference that exceeds by $1.3-1.5^{\circ} \mathrm{C}$ the value of the vertical average thermal gradient (which is $1^{\circ} \mathrm{C} / 232 \mathrm{~m}$ ) of the foehnal air circulation.

In terms of hygrometric changes, the effects of the foehn are transposed by decreases of almost $8-9 \%$ of the average humidity values between the Humosu and Cotnari - Belcești weather stations, under the conditions in which the vertical vertical gradient specific to the Moldavian Plain $(0.5 \%$ / $100 \mathrm{~m}$ - [10] it would indicate for the same territory value decreases for this element of only $1 \%$ (Fig. 7). 

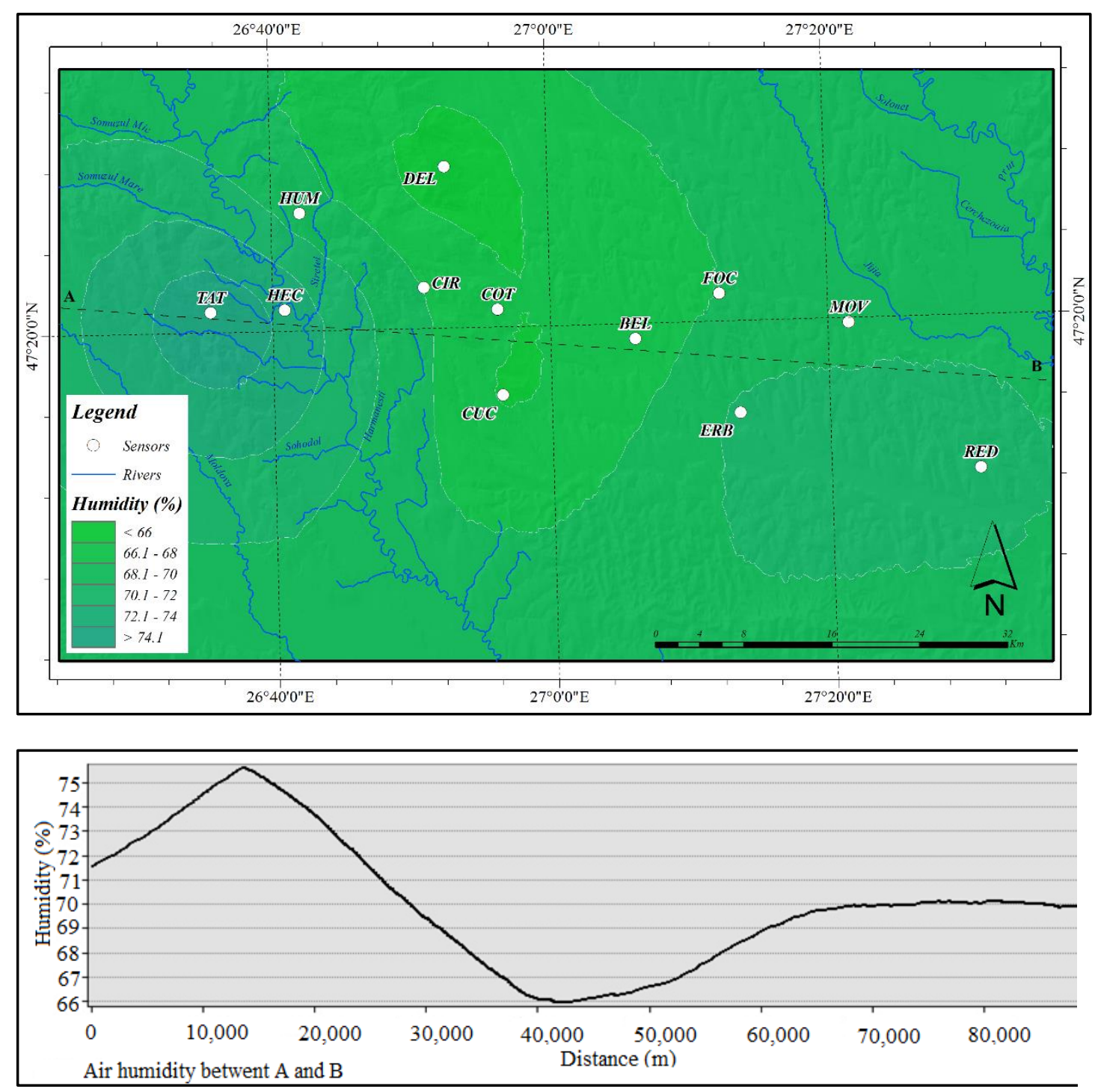

Figure 7. The relative humidity field at the height of $2 \mathrm{~m}$ from Cotnari surroundings - the average situation between 01.03.2019 at 00:30:00 and 31.10.2019 at 23:30:00 - above; the hygric profile between the western and eastern extremities of the investigated territory - below

The foehnal effects are felt more strongly in thermal and hygric plane to the east of Humosu over a distance of about 35-40 kilometers (Figs. 6 and 7), up to the CotnariBelcești localities. To the east of the Cotnari - Belcești weather stations, towards the JijiaPrut valleys the temperature drops slightly, and the humidity also increases slightly, the foehnal effects fading.

Analyzing Fig. 8, which represents the situation of the distribution of the average values of air temperature and humidity in the space related to Cotnari for the entire studied period, we can see the materialization of a turning point in the temperature and humidity of air at Humosu, a geographical landmark in the east, where the foehnal circulation becomes a reality through from its thermo-hygric effects. These influences are stronger until Belcești and then gradually fade as the distance from Cotnari - Belcești increases.

The characterization of the foehn in Cotnari, during the 8 months (between 01.03.2019 at 00:30:00 and 31.10.2019 at 23:30:00), is in the beginning stage of the researches, and these will be completed later by more case studies and for a cumulative period of two 
years (March 2019-March 2021). In this way, valuable topoclimatic conclusions will be drawn regarding the dynamics of the air in the investigated area.

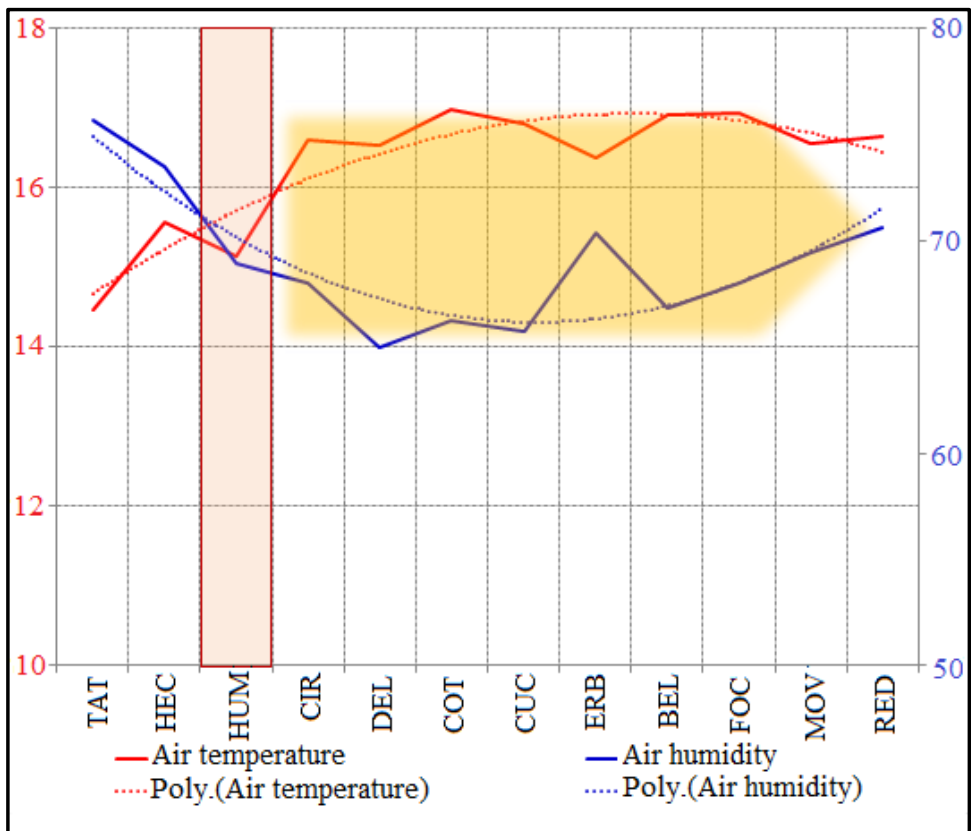

Figure 8. The temperature $\left({ }^{\circ} \mathrm{C}\right)$ and air humidity (\%) distribution at a height of $2 \mathrm{~m}$ in the geographical area of Cotnari between 01.03.2019 at 00:30:00 and 31.10.2019 at 23:30:00

The topoclimatic information will be supplemented by the longer term climate research (1960-2020), with the inclusion in the analysis of data from the Cotnari weather stations, but also of other weather stations located near it (Botoșani, Iași, Roman, Suceava).

\section{Case study regarding the foehn produced on 11.10.2019}

Proceeding to a more detailed investigation of one of the 20 foehn cases mentioned (Tab. 2 ), we could observe that in the typical situations with foehn, the temperature increase on the E-SErn slopes of the Moldavian Coast is higher in the direction of the Cotnary locality than indicates the average meteorological statistics (Fig. 6 and Fig.7). According to the data and the cartographic / graphical representations, the air temperature increase due to foehn (and which was added to the one due to the average vertical thermal gradient of almost $1^{\circ} \mathrm{C}$ to $200 \mathrm{~m}$ altitude difference) was in this case of $3.5^{\circ} \mathrm{C}$ (Fig. 9 ), and the decrease of the relative humidity due to foehn of $19 \%$ (Fig. 10). In this case we will also add the hygric difference due to the gradient of this element (of 1\% / $200 \mathrm{~m}$ ). Hence, the final result is that the hygric decrease between Humosu and Cotnari-Belcești can be attribuited, in a percentage of $95 \%$, to the foehn circulation. 

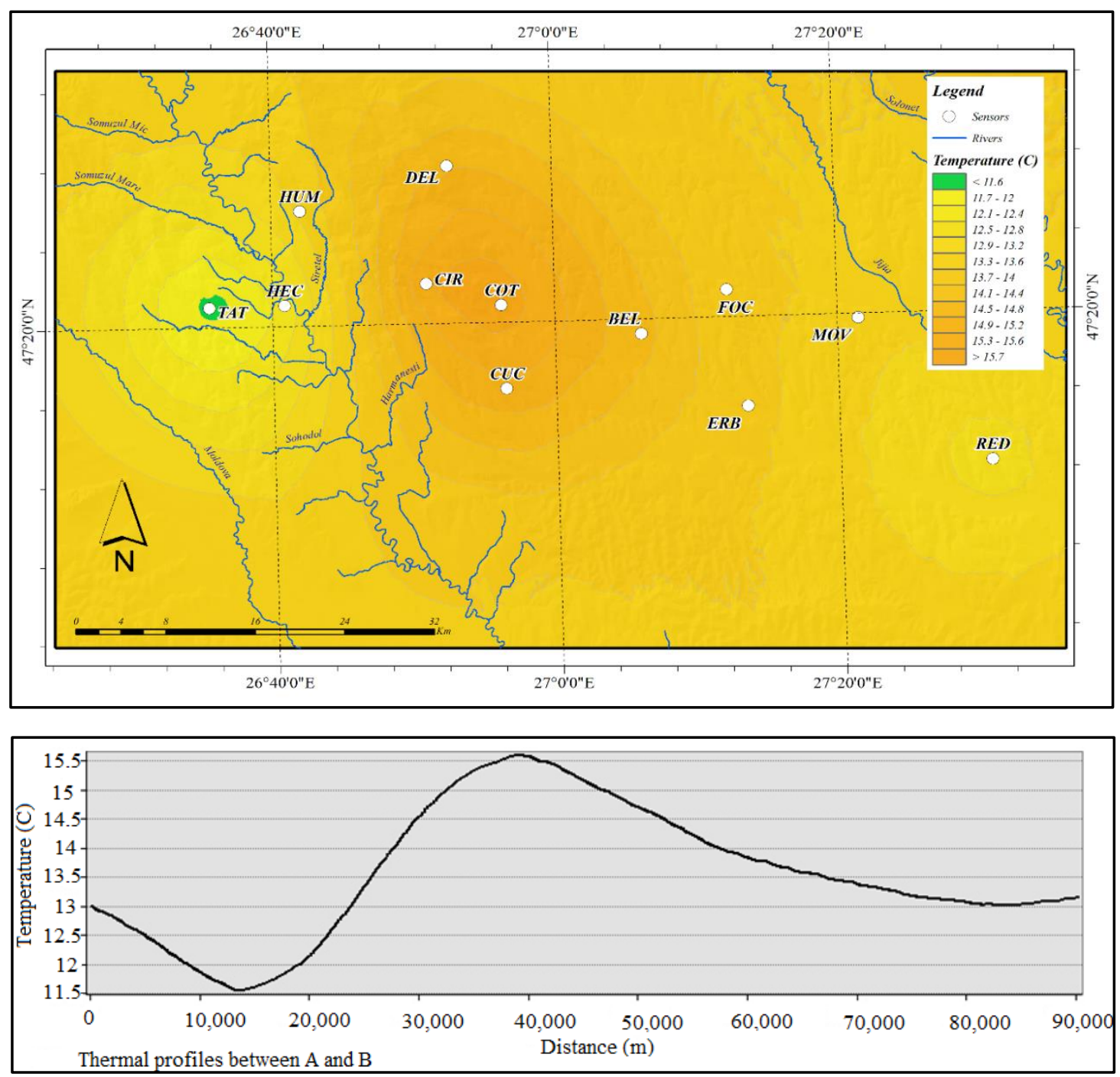

Figure 9. The thermal field at the height of $2 \mathrm{~m}$ in Cotnari surroundings - the situation between 11.10.2019 at 00:30:00 and 11.10.2019 at 14:30:00 - above; thermal profile between the western and eastern extremities of the investigated territory - below

The foehn episode unfolded between 11.10.2019 at 00:30:00 and 11.10.2019 at 14:30:00, graphically analyzed through Fig. 11 presents a series of particularities: the starting point, the extreme west of the triggering of the local foehn effects circulation is placed near the Humosu weather station, the thermal and hygric effects of the foehn are amplified over a distance of $25-30 \mathrm{~km}$ to the east, reaching the maximum in the perimeter of the CotnariCucuteni-Belcești weather stations, after which towards the valleys of the Jijia and the Prut, the characteristics are markedly differentiated from the area of maximum specified leaf influence. 

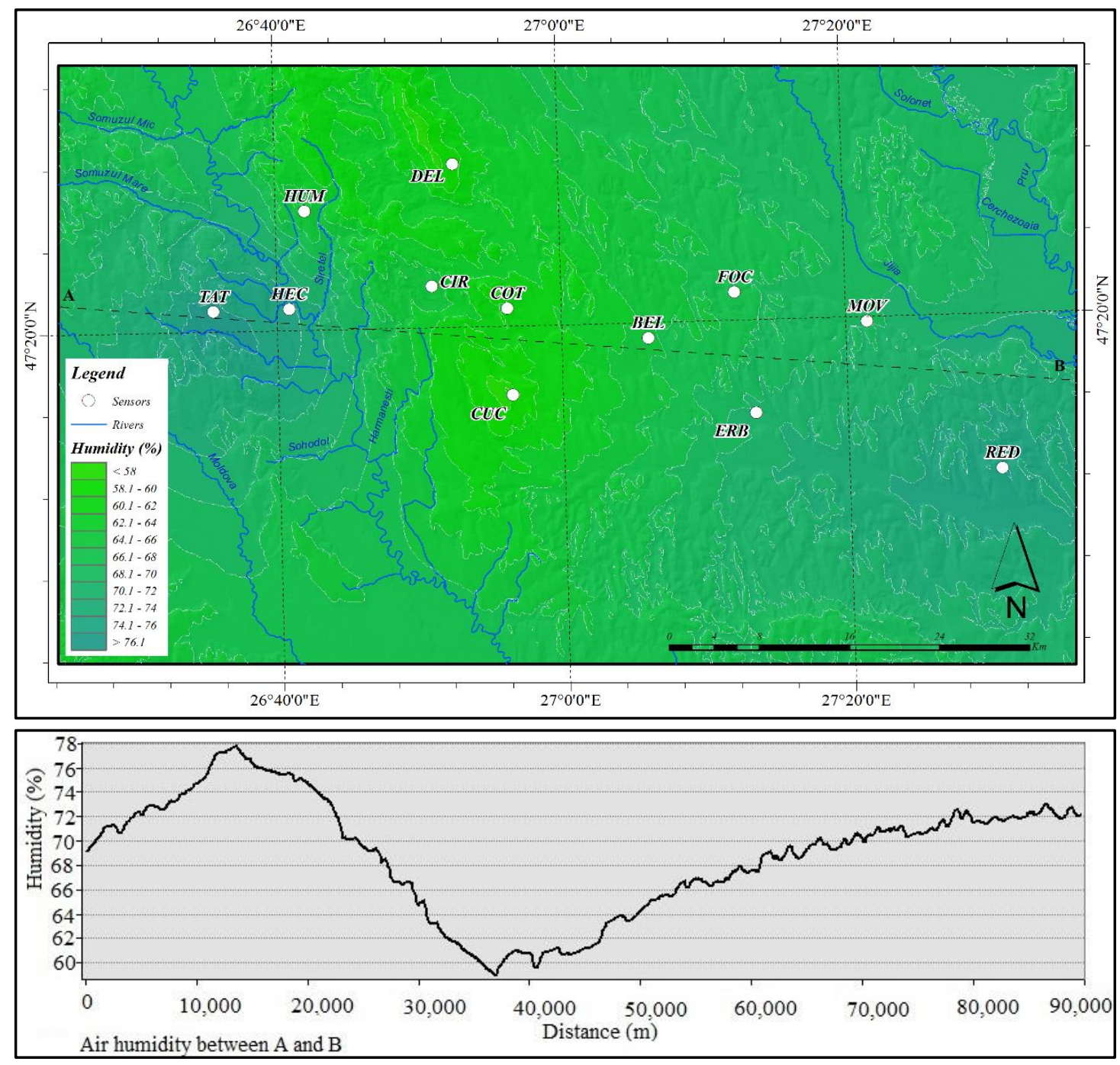

Figure 10. The field of relative humidity of the air at the height of $2 \mathrm{~m}$ from Cotnari surroundings - the situation between 11.10.2019 at 00:30:00 and 11.10.2019 at 14:30:00 - up; the hygric profile between the western and eastern extremities of the investigated territory - down

On 11.10.2019, in Europe the synoptic situation was characterized by the presence of an anticyclonic belt developed over the Atlantic Ocean and extended in the center, south and southwest of the continent. Northern Europe was under the influence of the Icelandic Cyclone, the lowest pressure being in the Norwegian Sea region, and the south was influenced by the Mediterranean Cyclone, which extended into northern Africa and the eastern sea basin.

The Cotnari geographical area was at that time on the front of the anticyclonal belt that occupied the center of Europe from west to east, in a position where the air circulation in the western sector was fully favored, the local-relief geographic factor playing its role of generator and amplifier of the observed foehn effects (Fig. 12). Consulting the meteorological data in the aerological context given by the air charts from 11.10.2019 from Bucharest (the only ones from outside the Carpathians with rele- vance and for the searched territory - the source of the diagrams: LRBS Bucharest Inmh-Baneasa) I could notice the fact that the movement of the air from the target area was carried out in a laminar flow, without significant shears and gusts (maximum wind speed was $7 \mathrm{~m} / \mathrm{s}$ ), 
which allowed the foehn area effects to materialize very well in the Cotnari-Cucuteni area -Belceşti.

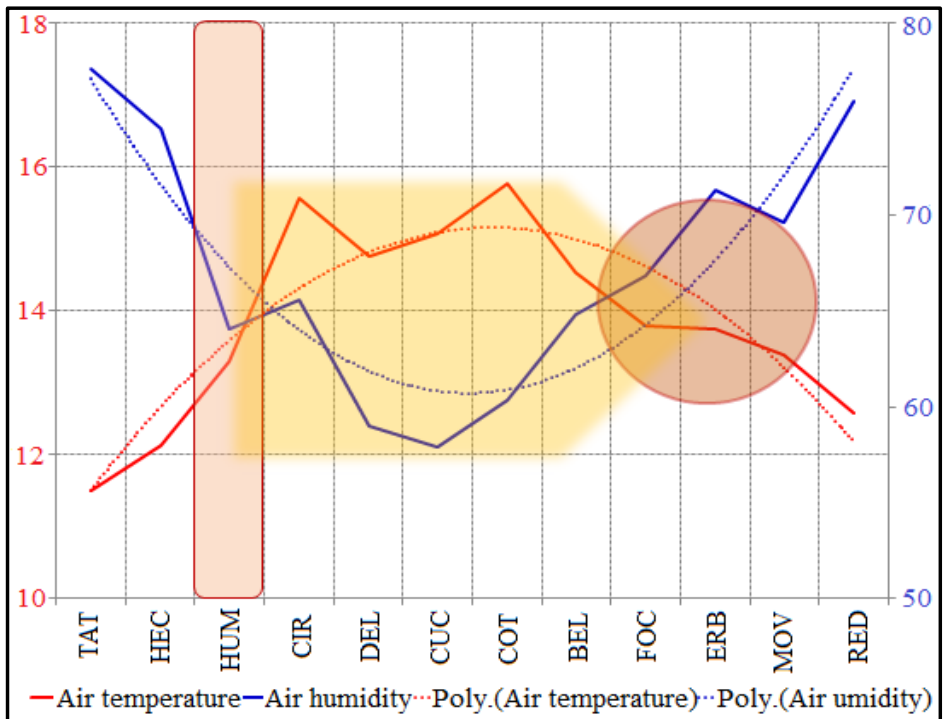

Figure 11.Temperature distribution $\left({ }^{\circ} \mathrm{C}\right)$ and air humidity (\%) at a height of $2 \mathrm{~m}$ in the geographical area of Cotnarilor between 11.10.2019 at 00:30:00 and 11.10.2019 at 14:30:00

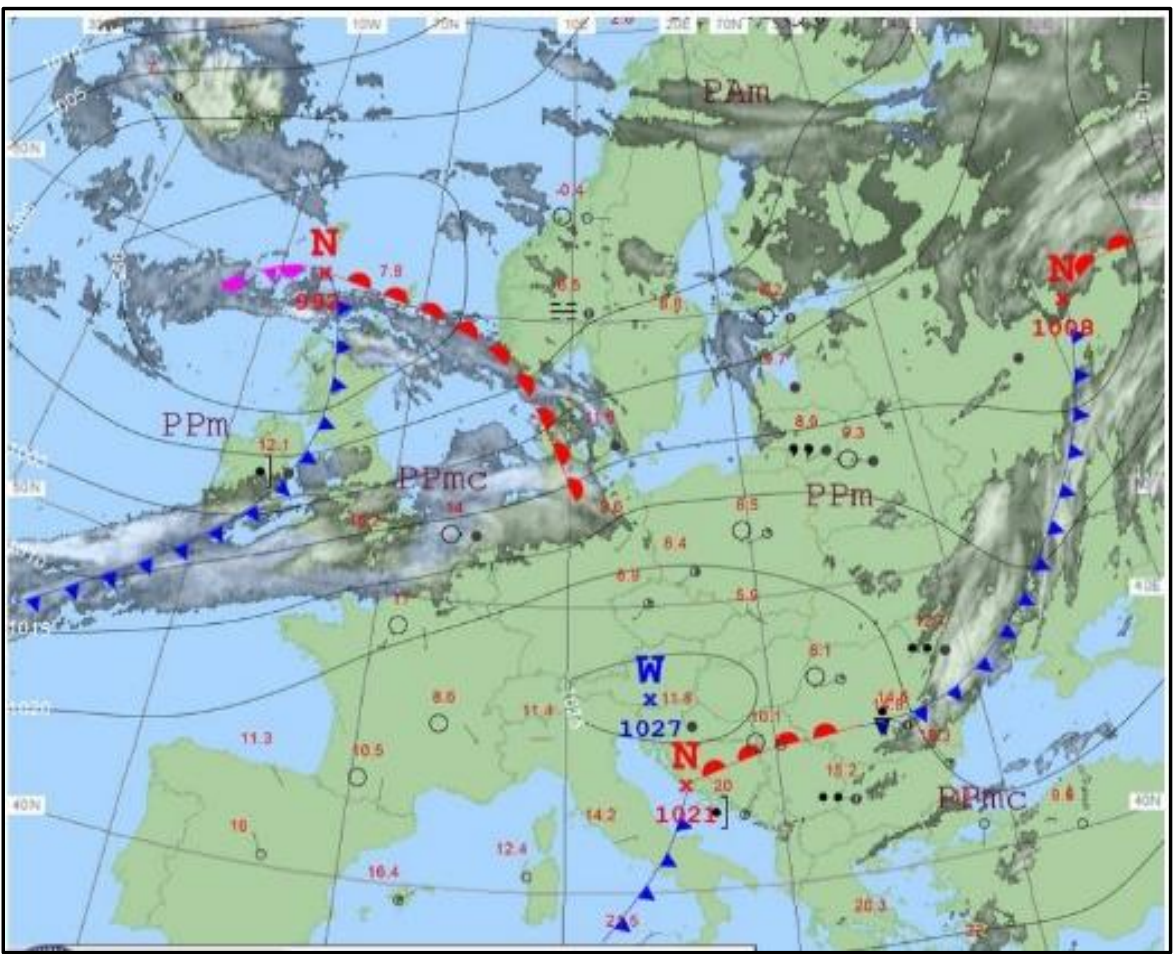

Figure 12. The synoptic situation in Europe on 11.10 .2019 at 13.00 (source: www.pogodynka.pl.)

Following the air temperature evolution during the night 11.10.2019 in a wider geographical context (the air temperature map for that interval consulted on the website: www.meteoromania.ro), we could notice the formation of the heat island in the Cotnari area, and at neighboring weather stations, the fact that the thermal values were lower than in the investigated area. 


\section{CONCLUSIONS}

The foehn in Cotnari is a local wind with meteorological consequences that can not be minimized. Monitoring for 8 months (between 01.03.2019 at 00:30:00 and 31.10.2019 at 23:30:00) the state of the weather in Cotnari area allowed us to draw important conclusions regarding the consequences of regional and local circulation.

The total duration of the foehn in Cotnari according to our preliminary research is $4.5 \%$ of the total observed time. The consequences of the foehn start at Humosu and reach the Jijia-Prut valleys, but are stronger over a distance of 25-40 km east of Humosu.

The area with the greatest thermo-hygrometric impact is that around the weather stations: Cotnari, Cucuteni, Belcești.

During the researched period, the foenal circulation led to a thermal advance of $1.3-1.5^{\circ} \mathrm{C}$ and to a hygric deficit of 8-9\%, in the territory situated at east of Humosu. In the period between 11.10.2019 at 00:30:00 and 11.10.2019 at 14:30:00 the consequences of the foehn were even more evident (the temperature increase was of $3.5^{\circ} \mathrm{C}$ in this case, and the value of relative humidity decrease of $19 \%$ due to the foehn).

These preliminary results entitle us to continue and deepen the research regarding the foehn in Cotnari, especially that the researched area is a vineyard of particular importance.

\section{Acknowledgement:}

This work is supported by project POCU 125040, entitled "Development of the tertiary university education to support the economic growth - PROGRESSIO", co-financed by the European Social Fund under the Human Capital Operational Program 2014-2020.

\section{REFERENCES}

[1] Billwiller R., Ueber verschiedene Entstchungsarten und Erscheinungsformmen des Foehns. J.Met.Zrit, 16, pp. 204-215, 1899.

[2] Brinkmann W.A.R., What is a foehn? Quarterly Journal of the Royal Meteorological Society, Institule of Arctic and Alpin Rechearch University of Colorado, pp. 230-240, 1971.

[3] Hächler P., Burri K., Duerr B., Gutermann T., Neururer A., Richner H., Werner R., Der Föhnfall vom 8.Dezember 2006 - Eine Fallstudie. Arbeitsber. MeteoSchweiz, 234, pp 52. 2011.

[4] Drobinski P. et.al., Föhn in the Rhine Valley during MAP: A review of its multiscale dynamics in complex valley geometry, Quarterly Journal of the Royal Meteorological Society, 133(625), Institule of Arctic and Alpin Rechearch University of Colorad, pp. 897-916, 2007.

[5] Bordei-Ion N., Foehnul Carpaţilor de Curbură si distribuţia precipitaţiilor în Bărăgan, St. Cercet., partea I-a, Meteorologie, Bucureşt, pp. 185-198, 1979, [in Romanian].

[6] Bogdan O., Un caz tipic de foehn în România, Studii şi cercetări de geografie, t.XXXVII, pp. 95-103, 1990, [in Romanian].

[7] Bogdan O., Foehnul carpatic, Univ. din Oradea, III, pag. 5, pp. 8-63, 1993, [in Romanian].

[8] Erhan E., Aspecte ale foehnizării aerului în estul României, Lucrările Seminarului geografic "D. Cantemir", nr. 23-24, Univ. "Al. I. Cuza”, Iaşi, pp.145-154, 2004 [in Romanian].

[9] Sfîcă L., Ichim P., Patriche C.V., Irimia L., Oană L., Cotnari vineyard- a gift of hydraulic foehn? Lucrările Ştiinţifice, vol. 57 / 2014, seria Agronomie, Iaşi, 2014

[10] Mihăilă D., Câmpia Moldovei. Studiu climatic, Editura Universităţii Suceava, 465, 2006, [in Romanian].

***WMO-The World Meteorological Organization, 1992

*** www. pogodynka.pl

*** www.meteoromania.ro 